International Journal of Arts and Humanities Studies (IJAHS)

ISSN: $2754-4311$

DOI: 10.32996/ijahs

Journal Homepage: www.al-kindipublisher.com/index.php/ijahs

\title{
Financial Literacy and Consumer Financial Well-being in Ghana: Any Nexus with Economic Stability?
}

\author{
Juabin Matey \\ Senior Research Assistant, Research, Innovation, and Development Directorate, Bolgatanga Technical University, Ghana
}

$\square$ Corresponding Author: Juabin Matey, E-mail: e.juabin@gmail.com

\section{ARTICLE INFO}

Received: 08 September 2021

Accepted: 14 October 2021

Published: 23 October 2021

DOI: $10.32996 /$ ijahs.2021.1.1.3

\section{KEYWORDS}

Financial literacy, Consumer financial stability, Economic stability, Household theory. Macroeconomic-level Microeconomic-level

\section{ABSTRACT}

Despite persistent efforts to deal with life's economic challenges, most Ghanaians are financially insecure, making the pursuit of lifelong goals more difficult. Given these realities, financial literacy and consumer financial stability appear viable strategies for promoting economic stability. This is because financial literacy can serve as a conduit for informed financial decisions at both the household and macroeconomic levels. A high human development index is an indication of a better welfare of the citizenry in the country. As a result, linking household decisions to broader policy outcomes is inevitable. In this work, efforts are made to establish a link between financial literacy and consumer financial stability and their relationships with macroeconomic stability. One significant finding is that financial literacy has a significant positive association with economic stability as measured by citizens' welfare. This discovery has several ramifications for national financial literacy initiatives. There appears to be an insignificant relationship between consumer well-being and economic stability, although positive. Nonetheless, it demonstrates how a financially secure consumer can boost aggregate demand by spending more, impacting job creation and macroeconomic growth. The Probit-Regression method facilitated data analysis using a participant population of 960 across eight studied regions in Ghana. Reasoning from these findings, national governments should take advantage of the favourable relationship between financial literacy and consumer financial stability on one hand, and national economic stability on the other seriously, as aggregate consumption volatility is lower in countries with a high level of financial literacy, which is reflected in individual saving and investment behaviour. As such, policy efforts should consider the relationship between microeconomic actions and macroeconomic outcomes since the former influences the latter.

\section{Introduction}

Citizens across the globe increasingly need strong financial literacy to take advantage of the livelihood opportunities available to them. Unfortunately, existing ideas of savings and investment are unreliable, have ceiling effects, and require a high level of abstraction. Individuals must manage their finances properly to survive and grow, which involves at least a basic comprehension of economic principles such as inflation and compound interest (Folke, Gjorgjiovska, Paul, Lea Jakon, \& Ruggeri, 2021). Financial literacy refers to individuals' capacity to easily handle financial affairs to enable them make informed decisions and weigh the risks and advantages of this feature (Buch, 2018). According to Hogarth (2006), financially savvy individuals are better equipped to make sensible financial decisions for themselves and their families, increasing their economic stability and well-being. As a result, a more secure family can engage in communal and participatory activities in their communities with confidence.

A year or two after Hogarth's research was published, the world experienced the economic crisis of 2007/2008, which appeared to have validated his findings. Individual consumers now recognize three realities: a poor financial decision has a cascading effect on

Copyright: (C) 2021 the Author(s). This article is an open access article distributed under the terms and conditions of the Creative Commons Attribution (CC-BY) 4.0 license (https://creativecommons.org/licenses/by/4.0/). Published by Al-Kindi Centre for Research and Development, London, United Kingdom. 
the economy, whether such a decision is made at the household or national level; accumulated behavioural threats that precede each crisis may go unnoticed; and finally, the systemic effects and cost of restoring the real economy may be anaemic and unsustainable (Hung, Parker \& Yoong, 2009). Beyond the 2007/2008 financial crisis, the lessons have awakened households and national governments to realise that financial stability at the family, community and macro levels absorb financial imbalances caused by endogenous events. These unforeseen events can be mitigated with educated family and community leaders, hence projecting the community's progress (Hogarth, 2006). Thus, household financial freedom influences the macro-level financial system's stability, critical for economic progress. Hung et al. (2009) observe that while the unintended consequences of insufficient savings and investment decisions on the individual and the larger community may be imperceptible in the short run, their longterm financial security consequences may be difficult to bear.

That being the case, the need to regulate the individual, real economic, and financial imbalances during thriving periods in the country should not be disregarded. It encourages saving behaviour and fosters investment for the system to weather tough financial times. With a similar economic and financial catastrophe, like the 2007/2008 occurrence, economies with transitory recognition of financial literacy are likely to experience an anaemic system recovery. As was the case during the global financial crisis of 2007-2008, many economies had a delayed recovery, owing partly to high levels of non-financial inclusion. While it is acknowledged that considerable progress has been made in terms of financial system regulation, more work must be done to achieve a more stable financial system capable of providing efficient services to the public [financial development] (Dudley, 2011).

Over the last couple of decades, educators, financial sector experts, business associations, governments, and legislators have engaged in lengthy debates over financial in/stability and financial il/literacy (Hogarth, 2006). Despite this considerable attention and publicity, an attempt by scholars to demonstrate a relationship between individual/household financial stability and economic system stability is glaringly absent. Financial industry stakeholders must raise awareness about the danger of financial instability at the household level and its power to influence macroeconomic stability. According to Ghana News Agency (2019), a National Strategy for Financial Literacy Education and Consumer Protection survey revealed that about $80 \%$ of Ghanaians are financially illiterate (see Matey et al., 2020). Thus, an informed and financially educated individual will be knowledgeable of the intricacies of saving, investing, inflation-related issues, and the importance of diversifying investments across asset classes. Additionally, the consumer must comprehend the financial stability concepts in terms of their constituents and metrics. There is therefore need to find out:

- If individual/household financial well-being impacts national economic stability

- Whether individual/household expenditure pattern influences national policy initiatives

\section{Literature Review}

Theories can reflect the emphasis of a wide variety of ideas, with the possibility of redefining these ideas and their associated notions (Mattila-Wiro, 1992). Thus, both the unitary and the collective household models (herein theories) have been maintained to reflect the significance of the household theory in economic stabilisation. A household is a collection of people (or perhaps an individual) who collaborates on economic activities necessary for survival and welfare enhancement. Given that households contribute to the economy by promoting economic and social interactions among citizens, and by maintaining reciprocal relationships with the economy, all micro and macroeconomic policy initiatives influence their structure and operations (MattilaWiro, 1999). Flexibility in one's life is a sign of worth, as it alleviates psychological stress and provides stability in family ties (Catanzaro, 2019).

This broader purpose of lowering an individual's psychological stress will not be attained unless and until human progress occurs in society. It is worrying that some traditional economists fail to recognise the household as a significant actor at both the micro and macroeconomic levels. It is a simple but deceptive attempt by national stakeholders to believe that individual welfare is limited to the family level (Mattila-Wiro, 1999). Academicians and governments should take caution when dealing with what this study refers to as the unitary household theory by acknowledging that a portion indeed creates a whole.

What appears to be a more far-reaching and, arguably, less evident benefit of financial literacy is the possible link between financial literacy, consumer financial well-being (stability), and community and macroeconomic development (see Catanzaro, 2019). If the needs of life (e.g., housing, health care, etc.) are met through prudent saving and informed investment returns, stability comes unofficially. This promotes continued child education and democratic community governance, including civic responsibilities that gradually morph into national assignments. With documented evidence, low levels of knowledge about financial concepts (Chen \& Volpe, 1998; Lusardi \& Mitchell, 2007; Lusardi, Mitchell, \& Curto, 2010; cited in Folke et al., 2021), coupled with their detrimental effect on economic stability (Lusardi \& Mitchell, 2011; Riitsalu \& Põder, 2016), will destabilise any attempt to link financial literacy and consumer financial stability on one side and economic stability/development on the other. 


\subsection{Financial Literacy and Economic Stability}

Financial Literacy Education is one field that bears a solid resemblance to economics as a social science. As such, most economic applications can find a comfortable home in FinLit-Education. Economists have come to accept that if the economy is presumed stable at every setpoint, consumer welfare will improve (Buch, 2018). As one of the objectives of this study, the Household Theory (both the unitary and the collective) is employed to establish a link between FinLit and Economic Stability. A stable economy is one in which citizens have access to the necessary information and resources to invest, grow, and participate meaningfully in all elements of economic activity at both the household and the national levels (Buch, 2018 and Mattila-Wiro, 1992). Households can comprehend loan conditions and obtain funds, purchase suitable housing, own a reasonable mode of transportation, and save for retirement or school. Since most economies are bank-based, economic stability and growth are frequently used interchangeably with financial stability. The financial markets' welfare implications explain this. According to a study conducted by Lusardi, Michaud, and Mitchell (2017), a well-functioning financial market can bolster an economy's growth strategy and project wealth generation through capital accumulation. In their opinion, bolstering an economy's growth strategy is a result of financial literacy instruction. Buch (2018) believes that concerns of financial stability require an aggregate view of financial knowledge; until this is achieved, financial stability is jeopardised, with catastrophic consequences for economic activity, including output loss and higher societal costs. This means that it is critical to understand the relationship between microeconomic decisions and macroeconomic outcomes.

Importantly, FinLit demonstrates its support to develop resilient economies through better allocation of lifetime resources in this global economy with uncertain and imperfect insurance (Buch, 2018 and Lusardi et al., 2017). This is because resilience assists in risk management and defuses threats to household welfare. Damayanti, Murtaqi, and Pradana (2018) argue for increased awareness of financial literacy considering its beneficial effects on micro and macroeconomic development. This position of the researchers is entirely consistent with the current study's objective, which is to analyze the relationship between financial literacy and economic stability (which is a condition for economic growth). This, they explain, will assist national governments in implementing economic policies in the stock market and halt any further escalation of inflation. Buch (2018), on a different level, connects financial literacy to financial stability, which is critical for most bank-based economies. Buch (2018) recognises that financial instability is inevitable if financial system shocks have a detrimental influence on the real economy, as this research aims to prove. Thus, financial system instability caused by low levels of financial literacy may hurt the real economy. Indeed, it is critical to emphasise that, while solid financial decisions at the household level are necessary for financial stability, they are not always sufficient. This is because households frequently overlook systemic risk externalities caused by their actions or inactions (Buch, 2018). Mian and Sufi (2018) establish a positive relationship between household decision-making and macroeconomic consequences in one empirical study. Their position is based on the global economic crisis, which they believe is partially the result of individuals' failure to seriously consider credit-driven business cycles.

\subsection{Consumer Financial Well-being and Economic Stability}

The private and global economies are inextricably linked in a variety of ways. As much as the instability of the unitary family influences the stability of the collective household, the more significantly transitively this influences the stability of any economy. This is because distortions in the collective household financial operations influence macroeconomic policies. The consumer is financially stable when he/she is not troubled about settlements of expenses or meeting daily financial obligations (Sutevski, 2021). As a member of society, financial literacy enables the consumer engage meaningfully in financial marketing, which contributes to economic progress (Busch, 2018). Financial literacy, evidence suggests, puts the household in a better position to engage in creditdriven activities (Mian \& Sufi, 2018). Another well-known example of being an informed consumer is avoiding excessive financial risk-taking, which mitigates the severity of the spillover effect on the national economy (Busch, 2018). Zahroh and Pangestuti (2014), as mentioned in Damayanti et al. (2018), reaffirm the importance of personal financial management skills in daily consumer choices that affect an individual's financial stability and way of living. Since personal welfare cumulatively reflects the soundness of the economy in many instances, Human Development Index performance is said to be favourable.

Economic stability is defined in this study in terms of economic progress. While economic stability does not always equate economic progress, it is necessary, as an economy cannot flourish in an unstable environment. According to Busch (2018), when analysing financial stability challenges, a holistic approach is required. Thus, the stress in individual finances could jeopardise the financial system's overall operation. In our situation, the financial system should be viewed as an economic system, as most economies are bank-based and rely on the financial the sector for stability. And so, financial sector distortions have a cascading effect on the real economy. Another study refers to the notion that the global financial crisis of 2007/2008 had a severe influence on citizens' living conditions, resulting in macroeconomic instability (Piece, 2012). Underdeveloped financial markets owe accountability in part to inadequate levels of financial numeracy, which is a component of financial literacy. Financial market participants must be informed about investible assets, credit cycles, and interest rates.

Main and Sufi (2011; cited in Boshara, 2012) established a relationship between declining aggregate demand and poor household financial health. This, they argue, was a cause to the economic recession between 2007 and 2009. Given that aggregate demand 
is a macroeconomic notion, financial instability among households is a forerunner to national economic instability. Furthermore, the study asserts that around 67 percent of employment losses in the United States (4 million out of 6.2 million) between 2007 and 2009 were attributable to the unhealthiness of consumer financial status, as stable income stimulates spending, which favourably influences aggregate demand. Boshara and Emmons' (2015) findings indicate that close to about three decades preceding the global financial crisis, consumer financial stability generated approximately $71 \%$ of national economic growth through spending. Economic growth is an indisputable contributor to economic stability. Boshara and Emmons (2015) discovered that a weak household balance sheet impairs consumers' ability to spend, contributing to unemployment, which further impairs consumers' spending patterns. Economic stability or development is not a one-sided issue; it is mainly motivated by its economic endeavour. Thus, Mattila-Wiro's (1992) household model is vindicated in this sense.

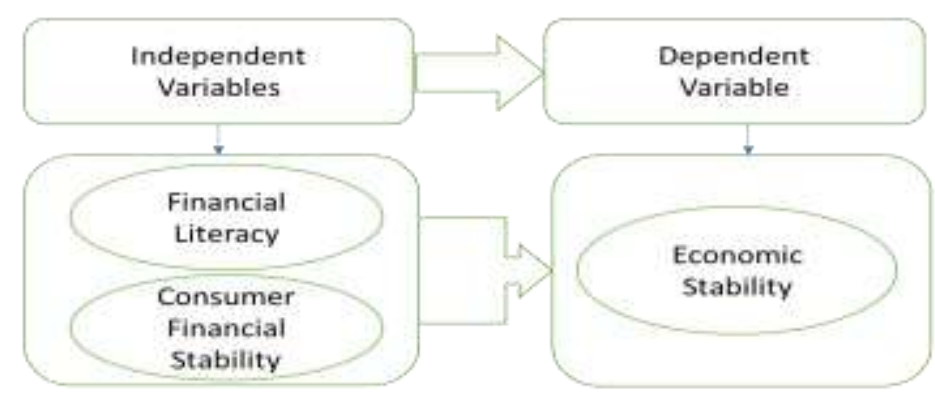

Figure 1: Conceptual Frame

Source: Researcher's construct (2021)

\section{Methodology}

Following Lusardi and Mitchell's (2008, 2011b, \& 2011c) works on assessing financial literacy using a set of questionnaires dubbed "The Big Three," this study assessed financial literacy through the use of these widely accepted concepts, which are primarily applied in the context of the consumer economic environment (Lusardi, 2019). Financial literacy, consumer financial stability, and economic stability are the three thematic areas covered in the study. Thus, Lusardi and Mitchell's (2008, 2011b \& 2011c) "Big Three" offered the measurement for the first thematic area (financial literacy). In the instance of consumer financial well-being (stability) the article analysed several suggested sets of questionnaires developed by academics worldwide, including that of Parker, Castillo, Garon, and Levy's (2016) from the Centre for Financial Services Innovation (CFSI). It arrived at an agreed-upon set of questionnaires containing five claims. As many economists are aware, economic stability (E-STABILITY) has been exposed to various assessment metrics, but none appears to have gained widespread public approval as an index. This study focused on the household as a unit for analysis purposes, with a sample size of 960 participants drawn from eight regions in Ghana. The sample is drawn based on the regional Human Development Index (HDI) performance by the United Nations Development Programme (UNDP) from 2018 to the present. Thus, the study defines economic stability in terms of the citizenry's economic well-being.

\subsection{Population, Sample, and Sampling Procedures}

As previously stated, the target population is Ghana's public sector employees. Due to budgetary constraints and concentration on research objectives, the study limited the sample to eight selected regions based on the UNDP's (2018) regional Human Development Index (HDI) performance. The report divides HDI into two categories: medium and low. As a result, a composite of participants from these two waves was created. The Greater Accra, the Western North, and Eastern Regions were chosen from the medium human development category, and the five Northern Regions (Upper East, Upper West, Savanna, Northeast, and Northern Region) were chosen from the low human development group. Take note that 2018 data were utilised as the base year. Participants were selected from the strata using a proportionate stratified sampling technique. A proportionate stratified sampling method is a sort of probability sampling that enables researchers to increase precision or decrease the margin of error. This strategy divides the population into non-overlapping segments using similar elements and pre-determined relevant characteristics for the investigation. The study's specific features included gender, education, and marital status (Sage Research Methods, 2010). After stratifying the population into eight (8) groups, one hundred and twenty (120) participants were randomly chosen from each of the eight groups to complete a sixteen-item questionnaire. As a result, the sample size was 960 .

\subsection{Data type}

To reach a reliable conclusion, primary and secondary data were analysed. The study used electronic mails, telephone calls, faceto-face meetings, WhatsApp, and a drop-and-pick instrument administration. Secondary data included published data from surveys conducted by international and national research organizations such as the UNDP and the CFSI on financial literacy education, among others. 


\subsection{Dependent variable}

Economic stability (Development) was used as the outcome variable in this study to refer to the citizenry's economic well-being. To elicit responses from participants, the study developed a set of 10-Likert scale statement questionnaires. Participants were instructed to rate sub-statements on a scale of 1 to 10. The closer a participant's score to 10, the higher and favourable their human development index ( $\mathrm{HDI})$ or sense of well-being, and vice versa. For example, under the sub-dependent variable of life expectancy, questions such as "How would you rate your access to health care and its quality?" or "How would you rate your general hygiene on a scale of 1 to 10?". All scores between 1 and 5 were categorised as 1, while those between 6 and 10 were likewise marked as 0 . Due to the binary nature of the coding chosen, these scores were aggregated for ease of data entry into Excel and then exported to Eviews 9.0 and STATA 14 softwares to run a Probit regression. Note that there are numerous measures of economic well-being used throughout the world, but for this study, which is mostly behavioural, the UNDP Human Development Index was adopted to determine economic well-being of participants.

\subsection{Independent variables}

Financial literacy and consumer financial well-being (stability) were used as regressor variables in this study. Lusardi and Mitchell's (2008, 2011b, and 2011c) papers serve as benchmarks for assessing financial literacy using "The Big Three" (see also Klapper \& Panos, 2011; Sekita, 2011; Watanapongvanich, Binnagan, Putthinum, Khan \& Kadoya, 2020). In the context of consumer financial well-being (stability), the study used Parker et al.'s (2016) CFSI proposed metric for determining consumer financial health (consumer financial stability). The readership should appreciate that the metric is modified to suit the current study. Consumer financial health is measured using four components (Plan, Spend, Save, and Borrow), all of which influence macroeconomic stability. Participants were given statements to rate on a scale of 1-3. For instance, under Spend, included a remark such as: On a score of $1-3$, how would you describe your expenditure pattern over the last year?

Spend much less or a bit less than earned income

Spend about equal to earned income

Spend a bit more than or much more than earned income

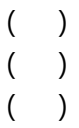

This question was preceded by a benchmark as follows.

\section{Benchmarks}

\section{Green Expenses < Income [1] \\ Yellow Expenses = Income [2] \\ Red Expenses > Income [3]}

Scores 1 and 2 were categorically assigned a value of 1 , while score 3 was likewise assigned a value of 0 . Thus, all recategorised scores of 1 to the three sub-items indicated a stable or somewhat stable financial situation, whilst a value of 0 indicated a financially unhealthy condition.

\subsection{Variable definitions}

Table 1: Variable definition

\begin{tabular}{|l|l|}
\hline Variable & Definitions \\
\hline Economic Stability / Development & Binary variable: $0=$ (scores between 1 and 5 ) and $1=$ scores from 6-10 \\
\hline Financial Literacy & Continuous variable: correct answers provided to "THE BIG THREE" \\
\hline Consumer Financial Stability & Binary variable: $0=($ scores between 1 and 2 ) and score $1=1$ \\
\hline Sex & Binary variable: Male $=1$ and Female $=0$ \\
\hline Age & Age in years of participants \\
\hline Education & Binary variable: 1 st Degree and above $=1$ and Below 1st Degree $=0$ \\
\hline Marriage & Binary variable: Married $=1$, otherwise $=0$ \\
\hline
\end{tabular}

Source: Adopted with slight modification from Watanapongvanich et al (2020)

\subsection{Variable specification}

The purpose of this study was to determine whether financial literacy and consumer financial well-being (stability) in Ghana have any relationship with economic stability. The study first determined the association between household financial literacy and economic stability at the national level, and then separately estimated consumer financial well-being (stability) and economic stability (eqns. [1] \& [2] respectively). The two variables were then merged in a complete model to determine their joint effect on economic stability in equation (3). 
Thus, the study incorporated the models developed by Watanapongvanich et al (2020).

$E-S T A B I L I T Y_{i}=f\left(F L_{i} X_{i} \varepsilon_{i}\right)$

$E-S T A B I L I T Y_{i}=f\left(F S_{i} X_{i} \varepsilon_{i}\right)$

$E-S T A B I L I T Y_{i}=f\left(F L_{i} F S_{i} X_{i} \varepsilon_{i}\right)$

Where:

E-STABILITY = Economic Stability (Well-being of Consumers): stable or unstable economy

$\mathrm{FL}=$ Financial Literacy status of Participants

FS = Financial Stability of Participants

$X_{i}=$ Vector of the individual control variables

$\boldsymbol{E}_{i}=$ Error term

\subsection{Results and Discussions \\ 4.1 Descriptive statistics}

Table 2: Descriptive Statistics

\begin{tabular}{|l|l|l|l|l|l|}
\hline Variable & \multicolumn{1}{|c|}{ Obvs. } & Min & Max & Mean & Std. dv \\
\hline Male & 960 & 0 & 1 & 0.622 & 0.487 \\
\hline Age & 960 & 23 & 54 & 40.60 & 0.310 \\
\hline Marriage & 960 & 0 & 1 & 0.771 & 0.424 \\
\hline 1ST Degree+ & 960 & 0 & 1 & 0.663 & 0.476 \\
\hline FinLit & 960 & 0 & 1 & 0.361 & 0.434 \\
\hline FinStab & 960 & 0 & 1 & 0.356 & 0.482 \\
\hline Consumer Wellbeing & 960 & 0 & 1 & 0.366 & 0.482 \\
\hline
\end{tabular}

Source: Field Survey (2021)

Table 2 depicts the descriptive statistics for a sample of 960 respondents to questions about their biodata, financial literacy, and consumer financial well-being (stability) in Ghana, and their relationship with national economic well-being. Sixty-two (62) percent of these participants were male, with an average age of a participant being about 41 years. It is critical for readers to understand that these participants were experienced and had a higher response rate to issues raised in the questionnaires. 66 percent of participants had earned a first degree or a higher level of certification. Regrettably, according to the research standards, just roughly $26 \%$ of these respondents were financially literate. It indicates that, whereas a higher percentage (66 percent) of the respondent population obtained a first degree or higher, this does not appear to be a prerequisite for financial literacy expertise. A person may possess a higher degree but be financially illiterate. According to Ghana News Agency (2009) reports, a survey conducted by the National Strategy for Financial Literacy Education and Consumer Protection revealed that about $80 \%$ of Ghanaians are financially illiterate (see Matey et al., 2020). The Ministry of Finance and Economic Planning then, indicated in a similar evidentiary survey report that while workshops on financial literacy skills are organised, the knowledge gathered during these knowledge imparting workshops does not convert into behavioural change (Ghana News Agency, 2009).

Of the 26.3 percent who claimed to be financially stable (see Table 3), 6.9 percent were dissatisfied with their economic lives, despite their claim to financial stability. This is an affirmation that financial stability is necessarily not synonymous with economic well-being. The remaining 19.4 percent was economically satisfied. This 19.4 percent category purportedly had their HDI being favourable by UNDP standards. Cross-tabulation of demographic factors vis-a-vis explanatory variables found that 613 (63.9\%) of the entire sample of 960 were financially illiterate. Indeed, there was a considerable difference in the gender makeup of this development; 61.6 and 38.4 percent, respectively, were male and female. Again, statistics indicated that approximately 24 percent of the sample who were financially knowledgeable were satisfied with their economic well-being. Among the other 64 percent who were financially illiterate, a staggering 56.7 percent indicated dissatisfaction with their financial condition and living standard. Females constituted 33.9 percent of this category. Surprisingly, 12.2 percent of those with financial instability reported having a

Page | 19 
comfortable economic life, compared to almost 61.5 percent who did not. The question then arises of whether financial stability is comparable to a fulfilled economic existence.

4.2 Cross-tabulation of respondent biodata side by side explanatory variables

Table 3: Distribution of self-reported Life Satisfaction using selected Demographic Characteristics of Participants

\begin{tabular}{|c|c|c|c|}
\hline Variable & Satisfied Economic Life & Unsatisfied Economic Life & Total \\
\hline \multicolumn{4}{|l|}{ Sex } \\
\hline Male & 31.9 & 29.7 & 61.6 \\
\hline Female & 4.50 & 33.9 & 38.4 \\
\hline Total & 36.4 & 63.6 & 100 \\
\hline \multicolumn{4}{|l|}{ Age } \\
\hline $24-29$ & 2.20 & 3.90 & 6.10 \\
\hline $30-35$ & 2.50 & 15.6 & 18.1 \\
\hline $36-41$ & 13.8 & 20.6 & 34.4 \\
\hline $42+$ & 17.8 & 23.6 & 41.4 \\
\hline Total & 36.3 & 63.7 & 100 \\
\hline \multicolumn{4}{|l|}{ Marriage } \\
\hline Yes & 28.1 & 48.6 & 76.7 \\
\hline No & 8.30 & 15.0 & 23.3 \\
\hline Total & 36.4 & 63.6 & 100 \\
\hline \multicolumn{4}{|l|}{ Education } \\
\hline 1ST Degree and Above & 15.8 & 50.6 & 66.4 \\
\hline Below 1ST Degree & 19.4 & 14.2 & 33.4 \\
\hline Total & 35.2 & 64.8 & 100 \\
\hline \multicolumn{4}{|l|}{ FinLit } \\
\hline No. of Correct Ans. & 23.8 & 12.3 & 36.1 \\
\hline No. of Wrong Ans. & 7.20 & 56.7 & 63.9 \\
\hline Total & 31.0 & 69.0 & 100 \\
\hline \multicolumn{4}{|l|}{ Con. FinStan } \\
\hline Scores $1 \& 2$ & 19.4 & 6.90 & 26.3 \\
\hline Score 3 & 12.2 & 61.5 & 73.7 \\
\hline Total & 31.6 & 65.4 & 100 \\
\hline
\end{tabular}

Source: Field Survey (2021 


\subsection{Probit Regression Results and discussion}

Table 4: Probit-Regression Results

\begin{tabular}{|l|l|l|l|l|}
\hline E-Stability & Coeff & Std. Error & Z-stats & $P>|z|$ \\
\hline Constant & -0.660 & 0.101 & 6.569 & 0.000 \\
\hline FinLit & 0.893 & 0.121 & 7.380 & 0.000 \\
\hline Obvs & 960 & & & \\
\hline Loglikelihood & -312.17 & & & \\
\hline AIC & 1.2607 & & & \\
\hline SC & 1.2859 & & & \\
\hline Prob & 0.0000 & & & \\
\hline
\end{tabular}

Source: Field Survey (2021)

*Due to the insignificant p-value of Consumer Financial Stability (Con. Stab), it is omitted from Table 4.

By employing inferential statistics and doing a Probit-Regression analysis (see Table 4), the study attempted to identify any conceivable link between financial literacy and consumer financial stability on one hand and macroeconomic stability on the other. It is argued that the existence of microeconomic stability at the household level implies improvement in macroeconomic conditions (Buch, 2018).

While the findings in this work are not as substantial as those in Buch's (2018) research on financial literacy and financial stability, they do contribute to the already established path connecting financial literacy and consumer financial stability to economic stability. At a $1 \%$ level of significance, there is a statistically significant association between financial literacy and economic stability. This finding is consistent with Catanzaro's (2019) assertion that once deliberate saving and investment fulfil basic needs like housing, clothing, and food, macroeconomic stability occurs automatically. This prerequisite extends to other sectors, including continued education, increased community participation in governance, and civic responsibilities for national assignment.

\section{Conclusion and Policy recommendations}

This study tried to establish any conceivable relationship between financial literacy and consumer financial stability, as well as how they act separately or in tandem to affect national economic stability. Improved financial literacy abilities is a conduit for better financial decisions at both the household (microeconomic) and national levels (macroeconomic level). Financial literacy works wonders in improving household knowledge of financial numeracy, which considerably enhances consumers' ability to make daily financial decisions. Financial literacy plays an endogenous role in the favourable relationship between consumer financial security and economic stability. Efforts required at the household level to maintain financial stability reflect those required at the macroeconomic level. When dealing with national economic stability challenges, the household/community should not be treated as a separate entity. This is because this study acknowledges that macroeconomic stability requires a chain of macro-prudential interventions to be successful. If the greater goal of national economic stability is to be followed, financial literacy and financial stability at the economic level should not be tackled separately. To summarise, this research emphasises the importance of taking the clear positive correlations between financial literacy and consumer financial stability on one hand, and national economic stability on the other seriously. Policy efforts should recognise the relationship between microeconomic decisions and macroeconomic results.

\section{Limitations and recommendations for further study}

Financial literacy has become a policy concern in this era of globalisation. As a result, any research conducted to demonstrate the subject's importance should be inclusive. The bigger sample size for this study should have included respondents from all 16 regions of Ghana if not an inter-country study. Additionally, instrumental factors would have aided in elucidating the causes for the explanatory variables' behaviour. Consumer financial stability, in particular, is insignificantly related to economic stability. Incorporating variables such as inflation, interest rates, and financial development would have shifted the direction of the study's findings. It is recommended that a study be conducted to revisit this current topic with the inclusion of these macroeconomic variables to cement any results. 


\section{References}

[1] Boshara, R. (2012). The household Balance sheet perspective. Federal Reserve Bank of St. Louis.

[2] Boshara, R., \& Emmons' (2015). A balance sheet perspective on financial success: Why starting early matters. Journal of Consumer Affairs 49(1). https://doi.org/10.1111/joca.12056

[3] Buch, C. (2018, March). Financial literacy and financial stability. A speech prepared for the $5^{\text {th }}$ OECDGFLECGlobal Policy Research Symposium to Advance Financial Literacy, Paris

[4] Catanzaro, M. (2019, April). What is financial literacy and why should you care?

[5] Damayanti, S. M., Murtaqi, I., \& Pradana, H. A. (2018). The importance of financial literacy in a global economic era. The Business and Management Review, 9(3), 435-441.

[6] Dudley, W.C. (2011, September). Financial stability and economic growth. A speech prepared at the Bretton Woods Committee International Council Meeting, Washington DC.

[7] Folke, T., Gjorgjiovska, J., Paul, A., Jakob, L., \& Ruggeri, K. (2021). Asset: A new measure of economic and financial literacy. European Journal of Psychological Assessment, 37(1), 6580. https://doi.org/10.1027/1015-5759/a000575

[8] Ghana News Agency (2009, September). $80 \%$ of Ghanaians are financially illiterate.

[9] Hogarth, J.M. (2006, November). Financial education and economic development: Improving Financial Literacy International Conference hosted by the Russian G8 Presidency in Cooperation with the OECD. Retrieved from https://www.oecd.org/finance/financial-education/37742200.pdf

[10] Hung, A. A., Parker, A. M., \& Yoong, J. (2009). Defining and measuring financial literacy. CERN Electronic Journal 708(708). https://doi.org/10.2139/ssrn. 1498674

[10] Lusardi, A., Mitchell, O. S. (2008, January). Planning and financial literacy: How do women fare?_National Bureau of Economic Research, Working Paper 13750 http://www.nber.org/papers/w13750.https://doi.org/10.3386/w13750

[11] Lusardi, A., Mitchell, O. S. (2011b). Financial literacy and retirement planning in the United States. Journal of Pension Economics and Finance 10(4): 509-525.

[12] Lusardi, A., \& Mitchell, O.S. (2011c). "Financial literacy around the world: An overview." Journal of Pension Economics and Finance 10(4), 497-508.

[13] Klapper, L., \& Panos, G. A. (2011). Financial literacy and retirement planning: the Russian case. Journal of Pension Economics and Finance, 10(4), 599-618.

[14] Lusardi, A., Michaud, P. C., \& Mitchell, O. S. (2017), Optimal financial knowledge and wealth inequality. Journal of Political Economy, 125(2). https://doi.org/10.1086/690950

[15] Lusardi, A., \& Mitchell, O. S. (2011). Financial literacy around the world: an overview. Journal of Pension Economics and Finance, 10(4), 497-508. http://doi.org/10.1017/S1474747211000448

[16] Lusardi, A., Mitchell, O. S., \& Curto, V. (2010). Financial literacy among the young. Journal of consumer affairs, 44(2), 358-380.

[17] Matey, J., Duut, J.Y., \& Kombian, M.F. (2020). Financial literacy education: Implication on the economic and social life of the teacher in Ghana. International Research Journal of Multidisciplinary Scope 2(1).14-27. https://doi.org/1047857/irjms.2021.v02101.046

[18] Mattila-Wiro, P. (1999, April). Economic theories of the household (Working Paper Series No. 159). UNU World Institute for Development Research (UNU/WIDER). https://www.wider.unu.edu/sites/default/files/wp159.pdf.

[19] Mian, A., \& Sufi, A. (2011). Household balance sheets, aggregate demand, and unemployment. The Pakistan Development Review, 50(4), 285-294. https://www.jstor.org/stable/23617699

[20] Mian, A., \& Sufi, A. (2018). Finance and business cycles: The credit-driven household demand channel. National Bureau of Economic Research. NBER Working Paper 24322. Cambridge MA.

[21] Parker, S., Castillo., N., Garon, T., \& Levy, R. (2016). Eight ways to measure financial health. Centre for Financial Services Innovation (CFSI).

[22] Piece, TT (2012). Macroeconomic stability, inclusive growth, and employment. UN System task team on the post -201, 5 UN Development Agenda.

[23] Riitsalu, L., \& Põder, K. (2016). A glimpse of the complexity of factors that influence financial literacy. International Journal of Consumer Studies, 40(6), 722-731. https://doi.org/10.1111/ijcs.12291

[24] Sekita, S. (2011). Financial literacy and retirement planning in Japan. Journal of Pension Economics \& Finance, 10(4), 637-656.

[25] Sutevski, D. (2021). What does financial stability actually mean for your brighter future?

[26] UNDP Human Development Report. (2020). The next frontier: Human development and the Anthropocene, Ghana.

[27] Watanapongvanich, S., Binnagan, P., Putthinum, P., Khan, M.S.R., \& Kadoya, Y. (2020). Financial literacy and gambling behavior: Evidence from Japan, Journal of Gambling Studies, Springer. https://doi.org/10.1007/s10899-020-09936-3

[28] Zahroh, F., \& Pangestuti, I. (2014). Testing the level of financial knowledge, personal financial attitude, and personal financial behavior of management department students, Faculty of Economics and Business Semester 3 and Semester 7. Doctoral dissertation, Faculty of Economics and Business. 